\title{
AUTOBIOGRAPHY, FICTION AND THE OVERCOMING OF ROMANCE. THE PARABLE OF THE OUTSIDER IN JOSEPH CONRAD'S THE SHADOW-LINE
}

\author{
Gianluca Cinelli \\ Institute for the History of the Resistance in Cuneo (ISRCN - Italy)
}

\begin{abstract}
The Shadow-Line represents a fundamental achievement in Conrad's literary career and constitutes the peak of the author's ethical reflection on the relationship between literature and life. By combining the autobiographical narration with the motives, atmospheres, and vocabulary of romance, Conrad presents the account of his personal experience of initiation to adulthood as a quest-like fiction of maturation through hardship. The key-figure of this merger is the "outsider," who is an individual who learns how to endure hardship and failure by opening his or her soul to solidarity and respect for humanity, thus achieving wisdom and ethical worth.
\end{abstract}

Keywords: Joseph Conrad, romance, realism, autobiography, outsiders in literature

\section{ROMANTICISM AND REALISM}

The Shadow-Line is, as Conrad himself recognised, a "fairly complex piece of work" that despite its brevity confronts the reader with a number of linguistic and interpretive problems. As suggested by the subtitle $A$ Confession and by the Author's Note of 1920, where Conrad writes that the tale was inspired by his own "obscure ... personal experience" (SL, 40), this work places itself between the autobiographic mode and the bildungsroman. ${ }^{2}$ The author's personal story is here represented in nonstrictly autobiographical terms, i.e. without organising the tale under a Lejeunian explicit "reading pact". ${ }^{3}$ The protagonist and narrator of The Shadow-Line, in fact, has no name and only a web of extra-textual references to Conrad's biography per-

\footnotetext{
${ }^{1}$ J. Conrad, The Shadow-Line, Harmondsworth: Penguin, 1986, p. 39. Hereafter cited as $S L$ in the text.

${ }^{2}$ F. Ciompi, Conrad. Nichilismo e realtà, Pisa: ETS, 2012, pp. 233, 235 and 251.

3 "Dans la biographie, l'auteur et le narrateur sont parfois liés par une relation d'identité [...]. On aperçoit déjà ce qui va opposer fondamentalement la biographie et l'autobiographie, c'est la hiérarchisation des rapports de ressemblance et d'identité; dans la biographie, c'est la ressemblance qui doit fonder l'identité, dans l'autobiographie, c'est l'identité qui fonde la ressemblance, l'identité est le point de départ réel
} 
mits to establish the connection between the narrator-character of the tale and the author of the book. ${ }^{4}$

However, as soon as one begins reading the first chapter, one gets lost in a tale that always seems on the brink of taking off and becoming the concrete account of actual experience, but which instead continuously comes to a stop, stagnates, and disperses in divagations and allusions, as far as "Conrad in the opening of The Shadow-Line exploits the gap between a character's perception and comprehension." Where readers would expect an "I" to introduce a confession, they instead come across an impersonal and rather vague "one" who recalls the dreamlike image of the enchanted garden of youth, at the end of which the domain of maturity begins. Such a border eventually becomes perceivable in the extraordinary metaphor of the "shadow line," which Conrad invented to describe such a vague and subjective experience, and yet real and universal, as the process of maturation through experience, which is the key to understanding the whole novel. Conrad's prose in the first two pages of The Shadow-Line suddenly plunges and re-emerges in a series of ellipses and allusions that require constant collaboration from the reader, who must follow the thread of the discourse among the divagations of the narrator. Thereafter, the tone of the tale becomes ironic and sometimes even sarcastic, as far as the childish and touchy narrator starts looking at the world with an overreacting feeling of irritability, which will in turn cause him to get angry at Captain Giles' patronizing maturity and to behave relentlessly against the Stewart of the Officer's Home.

One reason for such jamming of the autobiographical narration is that under its surface the deep waters of romance stir, which infiltrates autobiography with symbolism and allegory, ethical polarisation, and with the stylisation of human experience in the form of a quest, as Northrop Frye writes:

Romance is a "secular scripture", where the hero represents humanity and the quest he achieves the possibility of human existence. This in turn expands into a survey of the landscape of romance, in which there are themes of descent and of ascent. Descent takes the hero into lower and lower steps of consciousness, ending with death: ascent takes him up again to his original identity. ${ }^{6}$

According to Frye, romance seems as though it "were simply replacing the world of ordinary experience by a dream world, in which the narrative movement keeps rising into wish fulfilment or sinking into anxiety and nightmare." romance expresses the tension existing between reality and the desire of another reality, which generates a constant oscillation and polarisation of the opposites that fail

de l'autobiographie; la ressemblance, l'impossible horizon de la biographie." Ph. Lejeune, Le pacte autobiographique, Paris: Éditions du Seuil, 1971, p. 38.

${ }^{4}$ N. Sherry, "Conrad and the S. S. Vidar," The Review of English Studies 1963, 14(54), pp. 157-163; N. Sherry, "Exact Biography and 'The Shadow-Line,"” PMLA 1964, 79(5), pp. 620-625.

${ }^{5}$ A. Burns, "The Opening of The Shadow-Line," English Literature 1999, 80(6), p. 521.

${ }^{6}$ N. Frye, "The Secular Writing. A Study of the Structure of Romance" [in:] Collected Works, ed. J. Adamson and J. Wilson, Toronto: University of Toronto Press, 2006, p. 18:5.

${ }^{7}$ Ibid., p. 38. 
to harmonise with one another into a synthesis. The Shadow-Line is a novel impregnated with romanticism as far as Conrad's attitude

vacillates between reason and romance, and sometimes in critical situations, it modulates into romance. That is, Conrad sometimes moves from reality to unreality by choosing not to resolve the moral worries of his characters. Conrad escapes from coming to grips with the truth, either because he knows that it is unattainable or that simply once attained, it will make life meaningless. ${ }^{8}$

The young protagonist, who has a good reputation as a sailor, throws away a good job for no apparent reason and suddenly becomes an outsider in the British colony of Singapore: "One day I was perfectly right and the next everything was gone-glamour, flavour, interest, contentment - everything. It was one of those moments, you know. The green-sickness of late youth descended on me and carried me off. Carried me off that ship, I mean" $(S L, 45)$. Loss of status is a typical structure of romance as well as the entanglement of dream and reality, ${ }^{9}$ which in the novel is made clearly visible in the vocabulary, in some metaphors that Conrad uses, and in the representations of landscape which often resemble dreamlike visions rather than real places. The quest of the young narrator is not symbolic but existential as far as it is aimed at conquering self-knowledge and at penetrating the secret of life, which depicts the fall of the young man not in religious terms but as a quest for meaning in a world that is apparently void of God as well as of high truths which one can believe in. ${ }^{10}$ To explain my last statement, I will find it useful to refer to another critic who more sharply than Frye interprets romance in terms of political and social struggle with the real world:

Romance is that form in which the world-ness of world reveals itself. For romance, then, both uses of the term are appropriate, for romance as a literary form is that event in which world in the technical sense of the transcendental horizon of my experience becomes precisely visible as something like an innerworldly object in its own right, taking on the shape of world in the popular sense of nature, landscape, and so forth. ${ }^{11}$

According to Jameson the dialectic of good and evil always reflects socio-economic development: "Romance as a form thus expresses a transitional moment, yet one of a very special type: its contemporaries must feel their society torn between past and future in such a way that the alternatives are grasped as hostile but somehow unrelated worlds," ${ }^{12}$ hence the symbolic clash between the real and the imaginary, experience and dream, which permeates romance. In 1915, when he began to write

${ }^{8}$ A. Ayuk, Joseph Conrad's Tragic Moral Paradoxes, Paris: L'Harmattan, 2013, p. 28. Also Heart of Darkness presents a number of aspects in its language and structure that recall romance, from the theme of travelling into a dark, unknown land to the quest for Kurtz, who is by no accident referred to as an "enchanted princess sleeping in a fabulous castle." J. Conrad, Heart of Darkness, Harmondsworth: Penguin, 1989, p. 77.

${ }^{9}$ N. Frye, Anatomy of Criticism: Four Essays, Princeton, NJ: Princeton UP, 1971, p. 162.

${ }^{10}$ P. Wiley, Conrad's Measure of Man, Madison, WI: The University of Wisconsin Press, 1954, p. 200.

${ }^{11}$ F. Jameson, “Magical Narratives. Romance as Genre," New Literary History 1975, 7(1), p. 142.

${ }^{12}$ Ibid., p. 158. 
The Shadow-Line, Conrad must much likely have felt that the world, in which he had become adult and had achieved his important goals as a sailor and then as a writer, was on the brink of collapse and that the late Victorian culture that he had represented in his novels was going to be dramatically swept away by the Great War.

Thus, Conrad opted for telling a tale of initiation and self-assessment, as if to bridge between two ages of which he was witness and protagonist, as a man of action in 1888 (when he got his first command) and as a man of letters in 1915. The main theme of the novel is therefore the need of the individual for answers and directions to deal with reality in a moment of crisis. The parable of the young man in the novel is exemplary: he passes from throwing away his job, fortune, and social positionthe related career perspectives - to being entrusted the command of a ship thanks to the benevolent intercession of Captain Giles, an established, independent professional who takes the young stranded and talented outsider under his sympathy and protection. The first command then materialises as if miraculously and by magic, which introduces clear traces of romance into the novel. "Command" becomes a "magical word" and a "strong magic" $(S L, 62-63)$ that drags the young man from the Officers' Home to the Harbour Office, where powerful Captain Ellis appoints him with his first significant duty of adulthood, which will eventually turn out to be his quest. As he learns that he has to reach Bangkok to recover a ship whose last captain died at sea, he begins to imagine the ship as a beautiful woman waiting to be freed from her captivity to regain her liberty in the open ocean. As far as Captain Ellis' appointment is "only another miraculous manifestation of that day of miracles" $(S L, 68)$, the young man metaphorically "flies" back to the Officers' Home unable to elaborate the sense of the events according to any rational expectation:

I perceived that my imagination had been running in conventional channels, and that my hopes had always been drab stuff. I had envisaged a command as a result of a slow course of promotion in the employ of some highly respectable firm. The reward of faithful service. ... and now, here, I had my command, absolutely in my pocket, in a way undeniable indeed, but most unexpected: beyond my imaginings, outside all reasonable expectations ... it helped the feeling of wonder-as if I had been specially destined for that ship I did not know, by some power higher than the prosaic agencies of the commercial world. $(S L, 69)$

This is the moment that the structure of romance appears more explicitly, as the narrator becomes utterly unable to distinguish reality from dream, to the point that he must repeat that he then held his command unequivocally in his pocket, in the form of Captain Ellis' appointment letter:

Why was I not more surprised? Why? Here I was, invested with a command in the twinkling of an eye, not in the common course of human affairs, but more as if by enchantment. I ought to have been lost in astonishment. But I wasn't. I was very much like people in fairy tales. Nothing ever astonishes them. When a fully appointed gala coach is produced out of a pumpkin to take her to a ball Cinderella does not exclaim. She gets in quietly and drives away to her high fortune. $(S L, 72)$

The narrator's words here sound like a metanarrative reflection and a disguised poetic declaration: Conrad permits here romance to emerge with all its strength in 
order to grasp its deepest core, the dimension of juvenile enthusiasm, abstract and idealising, which is here caught in its last moment as the young man is about to abandon the "enchanted garden" of youth to enter into maturity. Thus, language becomes for a moment like that of fairy-tales: Captain Ellis has extracted a command "out of drawer almost unexpectedly as in a fairy tale" $(S L, 72)$; and the young man now thinks of his ship as of a woman to conquer: "A ship! My ship! She was mine, more absolutely mine for possession and care than anything in the world; an object of responsibility and devotion. She was waiting for me, spell-bound, unable to move, to live, to get out in the world (till I came), like an enchanted princess" (SL, 72). The ship as woman is an object of desire, conquest, and devotion in very idealising terms and to free her represents the "test of manliness, of temperament, of courage and fidelity - and of love" $(S L, 73)$ that anticipates initiation.

Like a knight of old the young man leaves the world of common men, who live ashore entangled in trivial affairs. Feeling mystically isolated in his quest, he at first dares not ask the captain of the Melita, who is accompanying him to Bankgok, what the ship looks like: "I was not going to expose the ship, my ship! to some slighting reference" $(S L, 78)$, like a devoted lover protects the beloved person from others' malicious glances and trivial jokes. And when he finally sees her, the tangle of emotions is described in physical terms: "Yes, there she was. Her hull, her rigging filled my eye with a great content. That feeling of life-emptiness which had made me so restless for the last few months lost its bitter plausibility, its evil influence, dissolved in a flow of joyous emotion" $(S L, 79)$. The view of the desired ship/woman suddenly fills the romantic soul of the narrator with new ardour and enthusiasm: "I knew that, like some rare women, she was one of those creatures whose mere existence is enough to awaken an unselfish delight. One feels that it is good to be in the world on which she has her being" $(S L, 80)$. And as he sees her trembling under the weight of a giant block of teak which is about to be lowered into her hold, he thinks that it is cruel to load her bosom in such a brutal way. The allusion to sex is quite evident and will become almost explicit as the young man finally steps on board with a "feeling of deep physical satisfaction" $(S L, 80) \cdot{ }^{13}$

The metaphoric conquest of the ship/woman, which occurs in such a sudden and amazing way, represents the conquest of love (spiritual and physical) and the affirmation of masculine maturity without the intermediation of social structures and rituals such as marriage. The double rejection of the two main axes of Victorian culture, namely work and conventional sexuality, seems to formulate Conrad's claim that the only real condition to affirm oneself is to ripen freely as individuals without abiding by restraining conventions. In romance there exists a socio-political component of rebellion to the establishment that Frye locates in the final evolution of romantic narrative, which is to say, in the "recognition scene": "It appears in the polarizing between two worlds, one desirable and the other hateful, the triumphant upward movement of the living hero rising from the dead dragon, the point that expresses the

${ }^{13}$ Frye writes that romance's eroticism concerns a lover "driven by his love to ascend to a higher world" ("The Secular Writing", 100) and that romance's "sexuality becomes a driving force with a great deal of sublimation in it" (120). 
reader's identity with a power of life strong enough to smash through any kind of barrier or danger." ${ }^{14}$ However, a need for mediation must be found between the juvenile drive to unconditional self-assertion and the effective self-positioning within one's own society. ${ }^{15}$

The parallelism between the unexpected professional appointment and the romantic conquest of love and happiness is not accidental, in fact the narrator insists on repeating that the command arrived not as the achievement of a long and honoured career but rather in advance on the cursus honorum which every professional should undertake in order to reach a prominent position. To trespass upon the shadow line in a world where self-affirmation means to establish oneself as homo oeconomicus therefore becomes an existential quest related with self-love and self-knowledge, ${ }^{16}$ which in a way explains the ambivalent feeling of the young man towards Captain Giles, in whom he acknowledges a priest rather than a seaman. Metaphorically, once again, Conrad seems to mean that real maturation for a human being does not consist in socio-economic success, although this greatly matters, but in attaining self-command and self-awareness, which includes the importance of failure as a highly formative experience, as Edward Said highlights as he writes that "the point of The Shadow Line - and the reason for its special beauty and courage - is that it begins with precisely this admission of failure, at that moment in life when all the hopes of youth have been exhausted in the continual search for new truths. For a sailor, as for a writer, this failure is not easy to admit." ${ }^{\prime 17}$

Thus, while on the one hand it is possible to acknowledge the presence and the importance of romance in the basic structure of The Shadow-Line, on the other hand it appears equally clear that the autobiographical basic pattern of teleological progress from crisis to self-assessment and self-knowledge is also at work in the tale. ${ }^{18} \mathrm{In}$ the case of Conrad's novel, though, the merger of fiction and romance permits to transcend the life-span perspective of autobiography and to idealise the single individual experience as a universally meaningful pattern, so as to acknowledge in the fracture of self-perception "a process of maturation triggered in the moment that one begins to think retrospectively about one's own life in search of identity." ${ }^{19}$ To such regard, Conrad's autobiographical inspiration participates in modernist aesthetics: "In place of the traditional life-narrative that traces the progress of the self as it moves toward, and ultimately claims, what is truly its own, modernist autobiography might concentrate on short periods of a person's life ...; or else it might restrict its focus to

${ }^{14}$ N. Frye, "The Secular Writing...," op. cit., p. 106.

${ }^{15}$ T. Lorch, "The Barrier between Youth and Maturity in the Works of Joseph Conrad," Modern Fiction Studies 1964, 10(1), p. 76.

${ }^{16}$ D. Schwarz, "Achieving Self-Command: Theme and Value in Conrad's 'The Shadow-Line,"” Renascence 1977, 29(3), p. 133.

${ }^{17}$ E. Said, Joseph Conrad and the Fiction of Autobiography, Cambridge, MA: Harvard UP, 1966, pp. $168-169$.

${ }^{18}$ F. D’Intino, L'autobiografia moderna. Storia, forme, problemi, Rome: Bulzoni, 2003, pp. 68-69.

19 "Un processo di maturazione che si innesca nel momento in cui si comincia a pensare retrospettivamente alla propria vita in cerca di un'identità." D'Intino, 79. Translation of the author. 
a particular, life-defining and often life-altering problem." ${ }^{20}$ The Shadow-Line is thus the re-enactment of a long autobiographical discourse in the wake of a new crisis which in 1916 urged Conrad to re-assess his juvenile experience in search of something he had not yet achieved, namely his peace of mind as a tormented individual and a homo duplex. Not only was he "a self-conscious foreigner writing of obscure experiences in an alien language, and he was only too aware of this," but "He had the courage to risk a full confrontation with what, most of the time, seemed to him to be a threatening and unpleasant world." ${ }^{21}$

\section{DIALOGUE, METAPHORS, AND VOCABULARY}

Once he has boarded his ship, the young captain begins to assess the effects and consequences of his conquest and his tale changes in tone and style. The stubbornly trenchant judgements which he dispensed in the first two chapters are now replaced by self-critical and introspective reflections, and his initial uneasy impatience gradually yields to a more challenging and profound doubtfulness. The capricious and touchy youngster has been left ashore and now in his place there is a commander who is for his first time taking a seat in the captain's cabin, where he can see himself mirrored in the compass as "self" and "other" at once: "This quietly staring man, whom I was watching ... had his place in a line of men whom he did not know, of whom he had never heard; but who were fashioned by the same influences, whose souls in relation to their humble life's work had no secrets for him" $(S L, 83)$. He now sees with the eyes of his mind his predecessors in whose footsteps one proceeds in youth ( $S L$, 43), for they are the representatives of a dynasty made not of blood but of professional bonds $(S L, 83)$. Responsibility and professional respectability make the dynasty and each new member must comply with such requirements. As one can therefore see, the romantic rebellion and the craving for independence are now questioned as the young captain enters his cabin and takes up his new role. ${ }^{22}$ Conrad seems here to be revisiting his own self-rescue from perdition and anonymity to a respected professional career as a sailor and eventually a successful writer, which confirms R. A. Gekoski's claim that in Conrad, "personal autonomy" and "social responsibility" are interdependent in a complex a multifaceted way. ${ }^{23}$ And in the way he blends autobiography with fiction one can also see how controversial was Conrad's perception of

${ }^{20}$ M. DiBattista and E. Wittman, "Modernism and Autobiography: Introduction” [in:] Modernism and Autobiography, eds. M. DiBattista and E. Wittman, Cambridge: Cambridge UP, 2014, p. xi.

${ }^{21}$ E. Said, Joseph Conrad and the Fiction of Autobiography, op. cit., p. 9.

${ }^{22}$ The "polarizing of action is obvious enough in romance; but the test of every revolutionary movement, however romantic, comes when it must establish continuity with what has preceded it" (N. Frye, "The Secular Writing...," op. cit., p. 95).

${ }^{23}$ R. A. Gekoski, Conrad: The Moral World of the Novelist, London: Edek, 1978, p. 22. 
Victorian colonial imperialism and mercantilism, in which he nevertheless found his way to self-affirmation. ${ }^{24}$

Already in the first two chapters, dialogue is used as the language-form that opposes fancies and reveries, and in dialogue the author always expresses some sound reality-principle that reaches its most self-conscious tone in Captain Giles' self-confidence. Dialogue is, since Plato, a mature instrument of interpretation of reality and a means of verification which everyone uses in society to assess one's own views and positions and to reason lucidly. By means of dialogue, Captain Giles convinces the young man to recede from his imprudent decision to quit his career and to go and get the job which is waiting for him. And by means of dialogue the good empathic doctor convinces the young captain to be prudent as he will sail with an ill-stricken crew and his first mate knocked-out by fever. And finally, by means of dialogue the courageous and generous Ransome will convince the doubtful and weary captain not to lose the grip on reality and to perform his task to the very end. Dialogue is therefore the anchor that language offers to the individual on the brink of going astray and getting lost in nonsensical blathering, as far as it is based on logical reasoning.

Treacherous are instead the dialogues between the young captain and Mr Burns who, entrenched in his monomaniac resentment against his former captain, attempts to convince the new commander to assume his own deranged theory of a supernatural curse cast on the ship. Unlike the dialogues with Captain Giles, the doctor and Ransome, which relieve the young captain from his oppressive feeling of solitude and isolation, that with Mr Burns casts him back into a threatening sense of loneliness and self-suspicion, which causes him to lose confidence in his abilities and soundness of mind and character, which is why Mr Burns delirious ravings represent the most dangerous trap for the young captain. ${ }^{25}$ Language in The Shadow-Line therefore seems full of traps and ambiguities, as far as each speech-act can have two meanings, as the narrator observes remembering the critical stage of his quest, as his ship was becalmed in the Gulf of Siam: "There were moments when I felt, not only that I would go mad, but that I had gone mad already; so that I dared not open my lips for fear of betraying myself by some insane shriek. Luckily I had only orders to give, and an order has a steadying influence upon him who has to give it" $(S L, 120)$. The dark side of this statement lies with the memory of the former captain's derangement, which produced unlawful orders out of grudge and madness (SL, 89-90).

Half-way between reverie and dialogue one finds private thought or rumination, which Conrad renders by means of free indirect speech and often by using verbless sentences that imitate intimate thinking. Another form that Conrad uses to express solitary thought is then diary, which represents a means to carry out self-criticism, to reflect and to find a way out from a complicated situation. ${ }^{26}$ Diary is cited twice in

${ }^{24}$ S. Ressler, Joseph Conrad: Consciousness and Integrity, New York: New York UP, 1988, p. 1.

${ }^{25}$ P. Wiley, Conrad's Measure of Man, op. cit., p. 210.

${ }^{26}$ According to A. Pizzorusso (Ai margini dell'autobiografia. Studi francesi, Bologna: Il Mulino, 1986, p. 90), diary is a way to educate one's own thinking; and to A. Girard (Le journal intime, Paris: Presses Universitaires Françaises, 1963, p. 533), diary is the place where one carries out self-questioning and conscience examination. 
The Shadow-Line and its mention always implies the idea of self-assessment and selfcomprehension, which makes of this form of writing a practice of self-analysis through detachment and critical reflection, although isolation is not only a powerful means of self-affirmation but also a dangerous condition that may lead one to blur the real perception of his condition with a view twisted by pessimism and despair. ${ }^{27}$

One of the difficulties with which this book confronts the reader is therefore the clash of the language of romance-which is allusive, vague, and confines with the sphere of dream - with that of autobiography - which is instead realistic, concrete, and precise. Both languages converge upon the common aim to make intelligible and comprehensible in terms of human finite and graspable experience the essence of such a universal, spiritual, and exceedingly unspeakable experience as the transit from youth to maturity. For this reason the tension between romanticism and realism emerges from Conrad's lexical choices that on the one hand draw from the sphere of the mysterious and even gothic ("bewitched," "fantastic horror," "malicious spectre," "ghastly," "evil spell," "curse," "ghosts," "animated skeleton," "inconceivable terror," "inexpressible mystery," "ominous appearance," "luminous appearance," "shadowy forms," "inconceivable depths," "mysterious devilry," "unearthly substance," and "mysterious rustle"), thus apparently connoting The Shadow-Line as a ghost-story or a tale of the supernatural. On the other hand, Conrad uses a lively and colloquial vocabulary (especially in dialogues) by often shaping it on nautical jargon ("quadrant," "trim the yards," "capstan," "bulwark," "spars," "leech-lines," "hatches," "halyards," "stove," "topmasts," "galley," "binnacle," "cabin," "furl," "trucks," etc.), which makes the prose of the novel sometimes even hyper-realistic.

By blending autobiographical writing and romance, Conrad gives birth to an individual-focused allegorical search for ethical and spiritual meaning against the background of a mercantile, trivial world, which makes the narrator of the book resemble Jameson's hero of romance, who is "something closer to an observer, a mortal spectator surprised by supernatural conflict, who then himself is gradually drawn in, to reap the rewards of victory without even quite being aware of what was at stake in the first place. ${ }^{28}$ Unlike romance, though, there is nothing supernatural in The Shadow-Line and everything is real, concrete, and experienced. ${ }^{29}$

The ghost of the former captain is not a real phantom but only the projection of two altered minds, namely that of Mr Burns whose hatred against his old captain has turned into monomaniac grudge, and that of the young captain who is afraid of failing his duty and of being unworthy of his fortune. Mr Burns' wild laughter by which he would exorcise the ghost of the dead captain is the actual depiction of a deranged state of mind disguised behind a veil of gothic images. Mr Burns is thus a double of the young captain as far as he is the physical projection of his fear of losing his grip

${ }^{27}$ A. Gillon, The Eternal Solitary: A Study of Joseph Conrad, New York: Bookman Associates, 1966, p. 102.

${ }^{28}$ F. Jameson, “Magical Narratives. Romance as Genre," op. cit., p. 139.

${ }^{29}$ R. Capoferro, "Providence, Anti-Providence, and the Experience of Time in The Shadow-Line," Conradiana 2015, 47(1), pp. 18-20. 
on reality, which therefore makes of Mr Burns a Jonah-figure. ${ }^{30}$ According to Benson, also Ransome is a double of the captain, for he sacrifices himself to save the ship and her illness-stricken crew despite his self-concern and "is employed significantly to emphasize the opposition of a sick heart, or soul, in a sound body and a sound soul in a sick body." ${ }^{31}$ The figure of the doppelgänger is crucial for Conrad as far as it permits to articulate a complex relation of participation and detachment between the author, his narrators and characters, and the narrative matter that is so often inspired by autobiographical memories.

The double plays an important ethical role in Conrad's fiction because his presence creates the depth and the perspective necessary to the author's mind to elaborate criticism and self-awareness in the face of his own experience and emotional background. ${ }^{32}$ However, Conrad's doppelgänger remains within the boundaries of realism, which connotes it as a metaphor of a moral experience of self-acknowledgement and self-questioning in connection with the experience of seclusion. ${ }^{33}$ Thus, as Marlow's negative double is Kurtz, so the young captain of The Secret Sharer meets his double in Leggatt, and the narrator of The Shadow-Line has a number of doubles in whom he can mirror his own fears, weaknesses, and virtues. The former crazy captain, too, is a double of the narrator as far as he was his predecessor in the ideal dynastic line of commanders, which he betrayed and disgraced by indulging his perverted desires, thus becoming the villain in the strongly ethics-polarised narrative scheme of romance. ${ }^{34}$ In the end, Mr Burns and Ransome represent the two opposite extremes of the moral latitude of the novel as far as the young captain acknowledges his own dark side and qualities by recognising them respectively in his first mate and in the cook. Their final portraits are therefore iconic, for Mr Burns appears as "a frightful and elaborate scarecrow set up on the poop of a death-stricken ship, to keep the sea-birds from the corpses" $(S L, 143)$ and Ransome as "a man listening for a warning call" $(S L, 145)$, which could be either the call of conscience or the certainty that everyone will sooner or later face death. In the end, the young captain will know that he possesses a strong character and a faint heart, which he will have to learn how to cope with. Thus, the tale that at first seemed to unfold in a wondrous and almost unreal way by obeying the desiring logic of dream, eventually reveals itself as a parable aimed at teaching that the most formative experience in life is dealing with the imponderable. Moving from fancy into experience, the narrator tells his story from the double standpoint of romance and of autobiographical narrative, and the joint between the two discourses is the absolute reality of the ship as an idea and a world, which is - as the narrator puts it - "the form concreting the abstract sentiment of ... command" $(S L, 80)$. Duality is therefore the main structure of The

\footnotetext{
${ }^{30}$ F. Masback, “Conrad's Jonahs,” College English 1961, 22(5), pp. 328-333.

${ }^{31}$ C. Benson, "Conrad's Two Stories of Initiation," PMLA 1954, 69(1), p. 53.

${ }^{32}$ Ch. Gramm, "The Dialectic of the Double in Lord Jim and 'The Secret Sharer," Conradian: Journal of the Joseph Conrad Society 2012, 37(2), p. 81.

${ }^{33}$ D. Yelton, Mimesis and Metaphor: An Inquiry into the Genesis and Scope of Conrad's Symbolic Imagery, The Hague: Mouton, 1967, pp. 276-277.

${ }^{34}$ N. Frye, Anatomy of Criticism..., op. cit., pp. 187-188.
} 
Shadow-Line, which is also the main structure of romance's polarised universe and in some way of the autobiographical dialectic between "then" and "now".

The great deal of metaphors that build the tale and its atmosphere permit to cross the boundary that separates the circumstantiated autobiographical memory from the idealised experience of maturing, which is expressed in the metaphorical trespassing on the shadow line..$^{35}$ Among the most relevant metaphors I recall the above-mentioned ship as a woman and the related metaphor of the ocean as freedom and pureness, opposed to land as the oppressing place of tropical heat and disease. While the romantic conquest of the ship/woman is just the condition for the quest, this is eventually represented by sailing upon the vast open ocean, which is what the captain strives towards. The ocean is the highest world of the romance which the young man craves for, where all his hopes and juvenile ardour will be fulfilled and satisfied. However, the conquest of the higher world will be possible only after the crossing of the underworld of deadly, becalmed waters which are a metaphor of the paralysis of the conscience, as the young captain doubts himself and his own abilities until he eventually writes in his diary notes of utter despair, in a moment of extreme seclusion and isolation. The tropical calm becomes even more sinister when Mr Burns' hallucinated mind transforms it into the fixed idea that the ship has been cursed, which makes the young captain understand that unchecked fancies in the long run become obsession and madness. For this reason, his struggle with Mr Burns is a metaphorical wrestling with his own consciousness and mind, a battle that is primarily fought in the ironic, reticent and often allusive dialogues between the narrator and the first mate.

If the calm is ambiguously rendered into the image of a real memory blurred with the fictive dreamlike - if not delusional - fruit of a feverish imagination, the only remedy to delirium and fever, quinine, is described by the narrator as a "magic powder working against mysterious malefices" that would protect the voyage "against the evil powers of calm and pestilence" $(S L, 110)$. Once again, reality of autobiographical memory is tampered with by means of an overload of romantic imagery, as far as magic and supernatural aids feature among the most common characteristics of romance. However, once again, the commander will pass the test by getting to grips with reality rather than by sinking into reveries and dreams, which is the typical way in which realism overcomes the romantic "naïve" imagery: "Just as the organizing ideas of romance are chastity and magic, so the organizing ideas of the high mimetic area seem to be love and form. And as the field of romantic images may be called an analogy of innocence, so the field of high mimetic imagery may be called an analogy of nature and reason." ${ }^{\prime 36}$ As Ransome calls the captain back to his senses, reminding him of his responsibilities, the officer answers as soundly as only a true commander

${ }^{35}$ The metaphorical representation of life as a journey is what George Lakoff and Mark Turner (More than Cool Reason: A Field Guide to Poetic Metaphor, Chicago: University of Chicago Press, 1989) call a basic metaphor, i.e. a pattern by which our mind configures our experience as an intelligible and meaningful story by starting from a basic bodily process such as motion. Trespassing upon the shadow line is a metaphorical stage of life as a journey (pp. 61-62).

${ }^{36}$ N. Frye, Anatomy of Criticism..., op. cit., p. 153. 
would: he goes back onto the deck to face the hardest of trials, which is also the last great metaphor of the book, the darkness of the night.

Darkness is the character's spiritual landscape and the acme of romance on the brink of dissolution, as the captain compares it to the terrible image of an imminent apocalypse ${ }^{37}$ In the moment of most painful isolation and oppressed under the weight of his "solitary responsibilities," the young man discovers the miracle of human solidarity in the courageous loyalty and obedience of Ransome, Gambril and the few men still able to work. ${ }^{38}$ The conquest of maturity is the real fulfilment of the juvenile unrest and rebellion, but without romantic inconclusive reveries and instead forged in the very heart of action and danger. The return to the starting point (Singapore) is formally the end of the quest, ${ }^{39}$ but the lesson that the young captain has learned stretches far beyond, for he knows that he still has to achieve the real aim of taking the ship into the Indian Ocean and back to England. As for himself, he has achieved much more, for he has found in solidarity the ethical sense of life, which Conrad eventually summarises in the metaphor of the heart, the enemy that the captain shares with Ransome: "Left alone in the cabin, I listened to him going up the companion stairs cautiously, step by step, in mortal fear of starting into sudden anger our common enemy it was his hard fate to carry consciously within his faithful breast" ( $S L$, 145). The two men less fit for success, an inexperienced young "outsider" and a heart-sick man, eventually turn out to be the real winners. Self-assertion and selfknowledge come in the end not as a philosophical act of speculation but rather as the test through which the young man has gained the right to be part in the community he wanted to belong to. And he eventually recognises that "he could not have survived the ordeal ... without a full reciprocity of dependence between himself and his crew. This lesson may seem banal enough; yet Conrad shows that it supports the entire edifice of human life." 40

As a number of critics have noted, The Shadow-Line is a tale of initiation, ${ }^{41}$ or the story of a rite of passage. ${ }^{42}$ Initiation to mature life is presented as a non-conform act of self-affirmation rather than a docile acceptation of social rules and roles and it is remarkable that one word summarizes the deep meaning of this experience: outsider. The outsider is not only one peculiar figure that appears over and over again in Conrad's narrative as an important metaphor of his imagery, but is also the embodi-

${ }^{37}$ Ibid., pp. 187-188.

${ }^{38}$ J. Peters, Conrad and Impressionism, Cambridge: Cambridge UP, 2001, p. 144.

39 "The quest is the cyclical structure of the cosmic journey reduced to the dimension of the individual, and it has a starting point and a point of arrival coinciding with the former" (N. Frye, "The Secular Writing...," op. cit., pp. 409-410).

${ }^{40}$ J. Berthoud, "Autobiography and War" [in:] J. Conrad, The Shadow-Line, Harmondsworth: Penguin, 1986, p. 14.

${ }^{41}$ C. Benson, "Conrad's Two Stories of Initiation," op. cit.

${ }^{42}$ C. Ginzburg, "Rites of Passage," The Threepenny Review 2000, 80, p. 29; O. Knowles, "Introduction" [in:] J. Conrad, The Shadow-Line, Cambridge: Cambridge UP, 2013, p. xxv. Modris Eksteins (Rites of Spring: The Great War and the Birth of the Modern Age, London: Black Swan, 1980) speaks of WW1 in terms of a rite of initiation from pre-modern culture into the modern one. 
ment of a determined attitude to life. ${ }^{43}$ As long as the young narrator of The ShadowLine remains ashore, separated from the sea which has so far provided him with social identity, he feels displaced and vulnerable and his defensive reaction towards the surrounding world (of whose arrogant colonial ruthlessness Hamilton is a living emblem) is emotional detachment, which plunges him into a dangerous state of atopia and melancholia. ${ }^{44}$ Captain Giles's benevolence is the only empathic means capable of penetrating the young man's impervious defence made of stubbornness, grumpiness, and indifference. However, precisely his state of atopia permits him to perceive his first command not as a regular achievement within the ruthless mercantile and colonial conventions, but as a unique personal success, which Conrad calls a "bit of one's own" $(S L, 43)$.

Thanks to his disadvantaged position, the young man can sharply recognise his weaknesses and qualities on which final success partly depends, and his being an outsider makes him ready to face whatever situation because he has nothing left to lose, for he is determined but aware of his limits and above all has no social masks on which he can rely to disguise his flaws. His character is to be revealed in what he will perform and his recognition will therefore go inseparable from the recognition of qualities and merits, which is in the end the acme of romance in the "recognition scene." ${ }^{45}$ As Conrad revisits his first success on which his fortunate reputation depended despite the unfortunate start, he reveals The Shadow-Line as the autobiographical sketch of an outsider, which implies a remarkable moral lesson, because to appreciate success ethically does not mean to be a man of "high professional reputation" (as the narrator defines Captain Giles while doubting his soundness of mind) $(S L, 57)$, but rather to learn how to know oneself and how to respect others and to be grateful in the face of their sacrifice. The young captain could be killed by his distraught men like Jonah, but they instead trust him and obey his command, which makes them worthy of "undying regard". The real test of manliness is, beyond any romantic symbolism, the ability of the young captain to find his own humanity in the encounter with the men of his crew, and his courage to affirm himself as a "successful outsider," which after all is what Conrad ironically wrote of himself in October 1907 to Edward Garnett, that he was an "amazing bloody foreigner writing in English."

The ultimate achievement and teaching of the tale is that experience is worthier than any abstract romantic idealization of life and that even with its disappointing

${ }^{43}$ It is no accident that Charles Marlow, too, is described in Heart of Darkness as an outsider: "The worst that could be said of him was that he did not represent his class", the narrator says and further on Marlow himself states that he felt like an "impostor" as he took the job in Brussels (J. Conrad, Heart of Darkness, op. cit., pp. 29 and 39). Also Lord Jim is in some ways an outsider, which in the end permits him to undergo the process of scapegoating that will put an end to his life. P. Armstrong, The Challenge of Bewilderment: Understanding and Representation in James, Conrad, and Ford, Ithaca, NY: Cornell UP, 1987, p. 117.

${ }^{44}$ A. Kowol, "Emotions versus Self-knowledge in Joseph Conrad's Lord Jim and The Shadow-Line," Yearbook of Conrad Studies 2016, 11, pp. 63-65.

${ }^{45}$ N. Frye, Anatomy of Criticism..., op. cit., p. 187.

${ }^{46}$ J. Conrad, Letters from Joseph Conrad, 1895-1924, ed. E. Garnett, Indianapolis: Bobs-Merrill, 1928, p. 205. 
moments and failures life - so Conrad seems to suggest - is broader and richer than art, and is in any case more potent. Art may dress reality and soften its asperities but cannot undo what was done or replace life with consolatory tales, although it may concede lapses of happiness and relief, as Conrad writes in the Author's Note, when he recalls "such events of one's life as one has no reason to be ashamed of" $(S L, 40)$. To learn how to occupy the place one deserves in the world is in the end what matters to live a good life.

\section{THE SHADOW-LINE AND WAR}

By blending two narrative styles (the romantic and the realistic) and two genres (the bildungsroman and the autobiographical novel) The Shadow-Line represents the universal experience of maturation by fictionalising the author's historical experience, where romance is eventually overcome by a narrative which looks at experience and ethics as the real driving forces which art should deal with. The question I would now like to answer is why the juvenile experience of his first command seemed to Conrad the only possible tale to tell for the time being $(S L, 40)$. As other critics have already pointed out, the war was the event that triggered again Conrad's interest in his first command after his son Borys went overseas to fight in 1915. ${ }^{47}$ According to Said, the war represented a "metaphysical rite of passage to which the world was submitting," ${ }^{48}$ and in that sense The Shadow-Line's ambition is to talk of the condition of many a great young officer deployed in the French trenches, who were called to make decisions on which the life of many other men depended, which makes of the tale a "resonant war-time parable." ${ }^{49}$

The inmost connection between the book and the war can be traced in language as far as it is no accident that the novel is so rich in military expressions like "enemy," "contest," "to fight," "to retire in disorder," "to face," "heroism," "endless vigil in the face of the enemy," etc. Nor seems superfluous to note the astounding similarity between two metaphors by which Conrad and Ernst Jünger respectively depict the nerve-shattering wait of the storm in the dead of night and the terrifying wait for action in a trench under heavy shelling: "It's like being bound hand and foot preparatory to having one's throat cut," the former writes $(S L, 125)$; and "you must imagine you are securely tied to a post, being menaced by a man swinging a heavy hammer," the German veteran writes. The same feeling of helplessness that makes the wait so feverish connects two experiences apparently so remote and diverse, but that actually share the same structure as far as they are both initiation experiences in which danger and a demanding call for duty forge the spirit of the young man by testing him to the

\footnotetext{
${ }^{47}$ J. Berthoud, "Autobiography and War," op. cit., p. 8.

${ }^{48}$ E. Said, Joseph Conrad and the Fiction of Autobiography, op. cit., p. 68.

${ }^{49}$ O. Knowles, "Introduction", op. cit., p. xxxv.

${ }^{50}$ E. Jünger, Storm of Steel, London: Penguin Random House, 2016, p. 82.
} 
limit. One letter written to John Quinn on $24^{\text {th }}$ May 1916 clearly reveals how much Conrad could see his son's experience reflected within his own recollections:

He [Borys] feels the responsibility in addition to the actual hard work. As he has no other officer with him he is kept on the stretch continuously. After all he is only just 18 . He can't have the mental and physical stamina of a mature man. ... On the other hand he talks affectionately of his Non-Com. officers who are very good to him, he says, and the men who are "dear fellows". He hadn't had to punish one of them ever since he is in command. In reality this means that they like the boy. And that's all right. ${ }^{51}$

Young age, inexperience, solitary responsibility of command, and lack of "mental and physical stamina" are far too familiar for the reader of The Shadow-Line s2 $^{2}$ and reveal that Conrad did not return to his biographical past because his creative imagination was exhausted but because he deliberately wanted to produce a work capable of synthetizing his ethical and formal concerns, as well as of establishing strong commitment in the face of present events, as the writer explained in 1917 to Sir Sidney Colvin:

If you will notice I call it A Confession on the title page. For, from a certain point of view, it is that - and essentially as sincere as any confession can be. The more perfectly so, perhaps, because its object is not the usual one of self-revelation. My object was to show all the others and the situation through the medium of my own emotions. The most heavily tried (because the most selfconscious) the least "worthy" perhaps, there was no other way in which I could render justice to all these souls "worthy of my undying regard." Perhaps you won't find it presumptuous if after 22 years of work I may say that I have not been very well understood. I have been called a writer of the sea, of the tropics, a descriptive writer, a romantic writer - and also a realist. But as a matter of fact all my concern has been with the "ideal" values of things, events and people. That and nothing else. ${ }^{53}$

The Shadow-Line has to do with self-revelation as much as with Conrad's metaphoric identification beyond time and space with a new generation called to pay for the sins and errors of the colonial and imperialistic world, in which Conrad was a young man who built his fortune as a sailor and as a writer. ${ }^{54}$ Borys' generation had been caught into the self-destruction of their fathers' world and were trespassing upon the archetypal shadow line once again. To tell in 1916 the tale of his first command was not therefore due to senile nostalgia but responded to the urge to attain the "ideal" through the account of a personal experience, and to retell the story of the eternal quest for finding oneself in what one does, in the lifespan which one is

${ }^{51}$ J. Conrad, The Collected Letters, ed. F. Karl and L. Davies, Cambridge: Cambridge UP, 1996, vol. 5, pp. 598-599.

${ }^{52}$ Another parallelism between the novel and Borys' condition emerges from the letter of 3 July 1916: "He [Borys]'s 'Very well, very tired, very busy.' Doesn't remember when he was last in bed." J. Conrad, The Collected Letters, op. cit., vol. 5, p. 614). In chapter 5 of The Shadow-Line the young commander hardly remembers when he was last in bed and Ransome must tell him that seventeen days have gone since the ship left Bangkok.

${ }^{53}$ J. Conrad, The Collected Letters, op. cit., vol. 6, pp. 38-39.

${ }^{54}$ J. Berthoud, "Autobiography and War," op. cit., p. 8. 
given to live..$^{55}$ The meaning of such ideal transfer of ethical wisdom from father to son is expressed in the dedication of the book to "Borys and all others who like himself have crossed in early youth the shadow-line of their generation." For this reason, I believe, the tale presents a number of semantic polarizations which can also be found in a great deal of war memoirs, such as darkness vs. light, high vs. low, young vs. old, open vs. closed, sane vs. mad, good vs. evil, and hero vs. villain. Such polarizations are reducible to the common literary form of romance and respond to the same expressive need for acknowledging in the private experience of suffering the repetition of a universal scheme - or myth - that is constantly re-enacted by means of literary representations. The tale tells about the loss of innocence and of the struggle with a deadly adversary, which in Conrad's extraordinary novel is not an external enemy to fight in the flesh but the frightening "outsider," the double who lurks inside the mind.

\section{WORKS CITED}

\section{Primary sources}

Conrad, Joseph. The Collected Letters. Ed. F. Karl and L. Davies. Cambridge: Cambridge University Press, 1996.

. Heart of Darkness. Harmondsworth: Penguin, 1989.

Letters from Joseph Conrad, 1895-1924. Ed. E. Garnett. Indianapolis: BobsMerrill, 1928.

. The Shadow-Line. Harmondsworth: Penguin, 1986.

\section{Secondary sources}

Armstrong, Paul. The Challenge of Bewilderment: Understanding and Representation in James, Conrad, and Ford. Ithaca, NY: Cornell University Press, 1987.

Ayuk, Athanasius. Joseph Conrad's Tragic Moral Paradoxes. Paris: L'Harmattan, 2013.

Benson, Carl. "Conrad's Two Stories of Initiation”. PMLA 69.1 (1954).

Berthoud, Jacques. “Autobiography and War". In J. Conrad. The Shadow-Line. Harmondsworth: Penguin, 1986.

Burns, Allan. "The Opening of The Shadow-Line". English Literature 80.6 (1999).

Capoferro, Riccardo. "Providence, Anti-Providence, and the Experience of Time in The ShadowLine". Conradiana 47.1 (2015).

Ciompi, Fausto. Conrad. Nichilismo e realtà. Pisa: ETS, 2012.

DiBattista, Maria, Wittman, Emily. "Modernism and Autobiography: Introduction". In Modernism and Autobiography. Eds. M. DiBattista and E. Wittman. Cambridge: Cambridge University Press, 2014.

D’Intino, Franco. L'autobiografia moderna. Storia, forme, problemi. Rome: Bulzoni, 2003.

Eksteins, Modris. Rites of Spring: The Great War and the Birth of the Modern Age. London: Black Swan, 1980.

Frye, Northrop. Anatomy of Criticism: Four Essays. Princeton, NJ: Princeton University Press, 1971.

${ }^{55}$ For an insightful analysis of the impact of WW1 on Conrad's life and imagery see M. Larabee, "Conrad and the Spaces of War," Conradiana 2014, 46(1-2), pp. 5-19. 
. "The Secular Writing: A Study of the Structure of Romance". In Collected Works.

Vol. 18. Eds. J. Adamson and J. Wilson. Toronto: University of Toronto Press, 2006.

Gekoski, R. A. Conrad: The Moral World of the Novelist. London: Edek, 1978.

Gillon, Adam. The Eternal Solitary: A Study of Joseph Conrad. New York: Bookman Associates, 1966.

Ginzburg, Carlo. "Rites of Passage". The Threepenny Review 80 (2000).

Girard, Alain. Le journal intime. Paris: Presses Universitaires Françaises, 1963.

Gramm, Christie. "The Dialectic of the Double in Lord Jim and 'The Secret Sharer"'. Conradian: Journal of the Joseph Conrad Society 37.2 (2012).

Jameson, Fredric. "Magical Narratives. Romance as Genre". New Literary History 7.1 (1975).

Jünger, Ernst. Storm of Steel. London: Penguin Random House, 2016.

Knowles, Owen. "Introduction". In J. Conrad. The Shadow-Line. Cambridge: Cambridge University Press, 2013.

Kowol, Agata. "Emotions versus Self-knowledge in Joseph Conrad's Lord Jim and The ShadowLine". Yearbook of Conrad Studies 11 (2016).

Lakoff, George, Turner, Mark. More than Cool Reason: A Field Guide to Poetic Metaphor. Chicago: University of Chicago Press, 1989.

Larabee, Mark. "Conrad and the Spaces of War". Conradiana 46.1-2 (2014).

Lejeune, Philippe. Le pacte autobiographique. Paris: Éditions du Seuil, 1971.

Lorch, Thomas. "The Barrier Between Youth and Maturity in the Works of Joseph Conrad". Modern Fiction Studies 10.1 (1964).

Masback, Frederic. “Conrad's Jonahs”. College English 22.5 (1961).

Peters, John. Conrad and Impressionism. Cambridge: Cambridge University Press, 2001.

Pizzorusso, Arnaldo. Ai margini dell'autobiografia. Studi francesi. Bologna: Il Mulino, 1986.

Ressler, Steve. Joseph Conrad: Consciousness and Integrity. New York: New York University Press, 1988.

Said, Edward. Joseph Conrad and the Fiction of Autobiography. Cambridge, MA: Harvard University Press, 1966.

Sherry, Norman. "Conrad and the S. S. Vidar". The Review of English Studies 14.54 (1963): 157-163. . "Exact Biography and 'The Shadow-Line"'. PMLA 79.5 (1964): 620-625.

Schwarz, Daniel. "Achieving Self-Command: Theme and Value in Conrad's 'The Shadow-Line"”. Renascence 29.3 (1977).

Wiley, Paul. Conrad's Measure of Man. Madison, WI: The University of Wisconsin Press, 1954.

Yelton, Donald. Mimesis and Metaphor: An Inquiry into the Genesis and Scope of Conrad's Symbolic Imagery. The Hague: Mouton, 1967. 